\title{
Pengaruh Pajak Kendaraan Bermotor Dan Bea Balik Nama Kendaraan Bermotor Terhadap Pendapatan Asli Daerah Dengan Pajak Bahan Bakar Kendaraan Bermotor Sebagai Pemoderasi
}

\author{
Ferdiansyah \\ Program Studi Akuntansi, Universitas Pamulang, Indonesia \\ dosen02423@unpam.ac.id
}

\begin{abstract}
The existence of motorized vehicles has become a very vital part of the community. So that it affects the increase in revenue from Motorized Vehicle Tax, Motorized Vehicle Transfer Fee Duties, Motorized Vehicle Fuel Taxes and Local Original Revenues. This study aims to determine the relationship of contribution of Motorized Vehicle Tax, Motorized Vehicle Transfer Fee Duty, Motorized Vehicle Fuel Tax to the Revenue of West Java Province. This type of research is associative with quantitative methods using the method of multiple linear regression analysis. From the results of the study showed that the Regional Tax consisting of Motorized Vehicle Tax, Motorized Vehicle Transfer Fee Duty and Motorized Vehicle Fuel Tax partially had a positive and significant effect on the Local Revenue. With Motor Vehicle Fuel Tax as a moderating variable simultaneously obtained positive and significant results, which means that it strengthens the influence between Motor Vehicle Tax and Motor Vehicle Title Transfer Fees on Original Income in West Java Province

Keywords: Regional Taxes, Motorized Vehicle Tax, Motorized Vehicle Transfer Fee Fees, Motorized Vehicle Fuel Taxes, Local Revenue
\end{abstract}

\begin{abstract}
Abstrak
Keberadaan kendaraan bermotor menjadi bagian yang sangat vital bagi masyarakat. Sehingga berdampak pada peningkatan pendapatan dari Pajak Kendaraan Bermotor, Bea Masuk Bea Balik Kendaraan Bermotor, Pajak Bahan Bakar Kendaraan Bermotor dan Pendapatan Asli Daerah. Penelitian ini bertujuan untuk mengetahui hubungan kontribusi Pajak Kendaraan Bermotor, Bea Masuk Kendaraan Bermotor, Pajak Bahan Bakar Kendaraan Bermotor dengan Pendapatan Asli Daerah Provinsi Jawa Barat. Jenis penelitian yang digunakan adalah asosiatif dengan metode kuantitatif dengan menggunakan metode analisis regresi linier berganda. Dari hasil penelitian menunjukkan bahwa Pajak Daerah yang terdiri dari Pajak Kendaraan Bermotor, Bea Balik Nama Kendaraan Bermotor dan Pajak Bahan Bakar Kendaraan Bermotor secara parsial berpengaruh positif dan signifikan terhadap Pendapatan Asli Daerah. Dengan Pajak Bahan Bakar Kendaraan Bermotor sebagai variabel pemoderasi secara simultan diperoleh hasil yang positif dan signifikan yang artinya memperkuat pengaruh antara Pajak Kendaraan Bermotor dan Bea Balik Nama Kendaraan Bermotor terhadap Pendapatan Asli di Provinsi Jawa Barat.

Kata Kunci: Pajak Daerah, Pajak Kendaraan Bermotor, Bea Balik Nama Kendaraan Bermotor, Pajak Bahan Bakar Kendaraan Bermotor, Pendapatan Asli Daerah
\end{abstract}

\section{PENDAHULUAN}

Sesuai dengan yang tertuang pada Pembukaan Undang-Undang Dasar 1945 yaitu "terwujudnya kehidupan masyarakat yang adil dan makmur". Pemerintah secara intensif melakukan berbagai macam kebijakan guna mewujudkan tujuan nasional tersebut. Untuk itu pemerintah baik pusat maupun daerah mencari upaya untuk mendapatkan pemasukan kedalam Pendapatan Negara. Dan untuk itu pemerintah meningkatan pendapatan baik pusat dan daerah dalam rangka mencapai tujuan pembangunan.

Kemandirian pembangunan diperlukan baik ditingkat pusat maupun daerah. Hal ini tidak terlepas dari keberhasilan pemerintah provinsi maupun pemerintah daerah atau kota yang merupakan bagian dari keberhasilan kebijakan pemerintah pusat. Adapun kebijakan tentang keuangan daerah dilakukan oleh pemerintah pusat agar pemerintah daerah dapat mengelola dan mengolah pendapatan daerahnya guna membiayai pembangunan daerahnya sesuai dengan prinsip otonomi daerah yang nyata dan bertanggung jawab. Penyelenggaran otonomi daerah harus selalu berorientasi pada peningkatan kesejahteraan masyarakat. Karena tujuan akhir dari otonomi daerah adalah mewujudkan masyarakat yang adil dan sejahtera.

Pemerintah daerah dalam menjalankan tugasnya, dimana pelaksanaannya memerlukan 
dana yang cukup besar, untuk itu pemerintah daerah berupaya peningkatan sumber-sumber penerimaan daerah. Adapun jenis pajak yang diatur dalam Undang-Undang Nomor 28 Tahun 2009 tentang perubahan atas Undang- Undang Republik Indonesia Nomor 34 Tahun 2000 tentang Pajak Daerah dan Retribusi Daerah untuk Provinsi dan Kabupaten/Kota. Dalam Undang-Undang Nomor 28 Tahun 2009 tentang Pajak Daerah dan Retribusi Daerah diatur mengenai jenis Pajak Provinsi yaitu; Pajak Kendaraan Bermotor (PKB), Bea Balik Nama Kendaraan Bermotor (BBNKB), Pajak Bahan Bakar Kendaraan Bermotor, Pajak Air Permukaan, Pajak Rokok.

Dari jenis-jenis Pajak Daerah, penerimaan yang memberikan pendapatan atau kontribusi cukup besar dalam peningkatan Pendapatan asli Daerah dalaam hal ini yaitu Pajak Kendaraan Bermotor dan Bea Balik Nama Kendaraan Bermotor. Keberadaan kendaraan bermotor telah menjadi bagian yang sangat vital. Selain karena kebutuhan, kepemilikan kendaraan bermotor tersebut menjadi salah satu alat ukur derajat seseorang di masyarakat, sehingga bagi sebagian masyarakat secara tidak langsung mereka akan berlomba-lomba untuk membeli kendaraan bermotor hanya untuk menunjukkan kemampuan atau derajat perekonomian mereka. Dari hal-hal tersebut maka permintaan akan kendaraan bermotor akan semakin meningkat bagi masyarakat saat ini. Dengan adanya kendaraan bermotor telah memudahkan mobilitas masyarakat, membuat efisien dan efektif dari setiap kegiatan masyarakat. Kendaraan bermotor merupakan salah satu objek pajak dari penerimaan pajak daerah. Konsumsi kendaraan yang tinggi oleh masyarakat akan meningkatkan jumlah penerimaan dari kepemilikan kendaraan bermotor tersebut. Kebutuhan konsumsi kendaraan yang tinggi akan didukung pula dengan kebutuhan jumlah bahan bakar untuk memenuhi kebutuhan kendaraan bermotor.

Peningkatan jumlah kendaraan bermotor tersebut dapat berpengaruh pada daerah, yaitu akan mempengaruhi penerimaan Pendapatan Daerah-nya. Pendapatan Daerah merupakan semua penerimaan uang melalui rekening kas umum daerah, yang menambah ekuitas dana, merupakan hak daerah dalam satu tahun anggaran dan tidak perlu dibayar kembali oleh daerah. Salah satu sumber dari Pendapatan Daerah tersebut adalah dari pajakpajak yang dipungut oleh Pemerintah Daerah. Dengan adanya peningkatan jumlah kendaraan bermotor tersebut, penerimaan dari Pajak Kendaraan Bermotor (PKB), Bea Balik Nama Kendaraan Bermotor (BBN-KB), dan Pajak Bahan Bakar Kendaraan Bermotor (PBBKB) tentunya akan mengalami peningkatan juga.

Kendaraan bermotor merupakan salah satu objek pajak dari penerimaan pajak daerah. Dengan berlakunya Undang-Undang yang baru tentang Pajak Daerah dan Retribusi Daerah yaitu Undang-Undang Nomor 28 Tahun 2009, terdapat peningkatan tarif dari pajak-pajak daerah tersebut. Untuk Pajak Bahan Bakar Kendaraan Bermotor dan Pajak Kendaraan Bermotor yaitu dari paling tinggi 5\% menjadi paling tinggi $10 \%$, untuk Bea Balik Nama Kendaraan Bermotor yaitu dari paling tinggi $10 \%$ menjadi paling tinggi 20\%, dan untuk Pajak Bahan Bakar Kendaraan Bermotor pemerintah menetapkan sebesar 5\%. Selain itu, terdapat perluasan basis pajak yang sudah ada, yaitu untuk Pajak Kendaraan Bermotor dan Bea Balik Nama Kendaraan Bermotor diperluas hingga kendaraan Pemerintah. Dengan demikian, Pemerintah Daerah semakin memiliki peluang untuk meningkatkan penerimaan Pendapatan Daerah-nya yang menjadi salah satu struktur Anggaran Pendapatan dan Belanja Daerah (APBD). Menurut Rositawati (2009:1), “Anggaran Pendapatan Daerah (APBD) adalah suatu rencana keuangan tahunan dari Pemerintah Daerah yang disetujui oleh DPRD dan ditetapkan oleh Peraturan Daerah". Sehingga dengan peningkatan dari pajak-pajak yang disebutkan di atas, akan menjadikan rencana keuangan APBD tersebut menjadi lebih mampu untuk menjalankan fungsinya dan mengurus rumah tangga daerah itu sendiri sesuai dengan kebijakan otonomi daerah yang telah diberikan

Berdasarkan hasil observasi penulis pada Kantor Cabang Pelayanan Dinas Pendapatan 
Daerah Provinsi Wilayah Kota Bandung III Soekarno Hatta - Bandung Timur Provinsi Jawa Barat diketahui bahwa masih rendahnya kesadaran dan pengetahuan masyarakat Provinsi Jawa Barat tentang pentingnya pajak.

Berdasarkan uraian tersebut diatas, maka penulis tertarik untuk meneliti kesadaran masyarakat akan kewajiban membayar pajak yang masih rendah, proses pembayaran Pajak Kendaraan Bermotor yang belum sepenuhnya dipahami oleh masyarakat. Adapun penelitian sebelumnya tentang Pajak Daerah dilakukan oleh Marisa Natalina (2013), Apri Mardiansah (2013), Riama Evi Aprianti (2013), Zulkifli (2013), Novita Ersady (2010), Muhammad Fayrusz C.E (2014), yang menyatakan bahwa Pajak Daerah berpengaruh positif dan signifikan terhadap Pendapatan Asli Daerah.

Tujuan penelitian Untuk mengetahui dan menganalisa pengaruh Pajak Kendaraan Bermotor dan Bea Balik Nama Kendaraan Bermotor terhadap Pendapatan Asli Daerah dengan variabel moderating Pajak Bahan Bakar Kendaraan Bermotor Provinsi Jawa Barat pada Cabang Dinas Pendapatan.

\section{KAJIAN TEORI DAN PENGEMBANGAN HIPOTESA Pengertian Pajak Daerah}

Menurut Undang-undang Nomor 28 tahun 2009 pasal 1 angka 10 tentang Pajak Daerah dan Retribusi Daerah, Pajak Daerah adalah kontribusi wajib kepada daerah yang terutang oleh orang pribadi atau badan yang bersifat memaksa berdasarkan Undang-Undang, dengan tidak mendapatkan imbalan secara langsung dan digunakan untuk keperluan daerah bagi sebesar-besarnya kemakmuran rakyat. Menurut Azhari Aziz Samudra (2015:68), "Pajak Daerah adalah pajak yang diipungut daerah berdasarkan peraturan pajak yang ditetapkan oleh daerah untuk kepentingan pembiayaan rumah tangga pemerintah daerah tersebut".

Pengertian Pajak Daerah menurut Marihot Pahala Siahaan (2010:9), "Pajak Daerah adalah iuran wajib yang dilakukan oleh daerah kepada orang pribadi atau badan tanpa imbalan langsung yang seimbang, yang dapat dipaksakan berdasarkan Peraturan Perundangundangan yang belaku, yang digunakan untuk membiayai penyelenggaraan pemerintah daerah dan pembangunan daerah".

Pengertian menurut Andi (2013:7), "Pajak Daerah adalah kontribusi wajib kepada daerah yang terutang oleh orang pribadi atau badan yang bersifat memaksa berdasarkan Undang-undang, dengan tidak daerah bagi sebesar-besarnya kemakmuran rakyat".

Dengan demikian dapat ditarik kesimpulan bahwa Pajak Daerah adalah pajak yang dipungut oleh Pemerintah Daerah kepada wajib pajak (orang pribadi atau badan) yang sifatnya memaksa berdasarkan Undang-Undang tanpa adanya kontraprestasi secara langsung, digunakan untuk membiayai keperluan daerah dan digunakan sebesar-besarnya bagi kemakmuran rakyat.

\section{Pajak Kendaraan Bermotor}

Menurut Peraturan Daerah Provinsi Jawa Barat Nomor 13 tahun 2011, "Pajak Kendaraan Bermotor adalah pajak atas kepemilikan atau penguasaan kendaraan bermotor". Kendaraan Bermotor adalah semua kendaraan beserta gandengannya yamg digunakan di semua jenis jalan darat, dan digerakan oleh peralatan teknik berupa motor atau peralatan lainnya yang berfungsi untuk mengubah suatu sumber daya energi tertentu menjadi tenaga gerak kendaraan bermotor yang bersangkutan, termasuk alat-alat berat dan alat-alat besar, yang dalam operasinya menggunakan roda dan motor dan tidak melekat secara permanen.

Sedangkan Kendaraan Bermotor Umum menurut Peraturan Daerah Provinsi Jawa Barat Nomor 13 tahun 2011, "Kendaraan bermotor umum adalah setiap kendaraan bermotor yang dipergunakan untuk mengangkut orang atau barang dengan dipungut bayaran dan memiliki izin penyelenggaraan angkutan umum dan izin trayek atau izin tidak dalam trayek".Dengan kata lain Pajak Kendaraan Bermotor adalah pajak yang dipungut oleh 
pemerintah daerah kepada wajib pajak baik pribadi atau badan atas penguasaan atau kepemilikan atas kendaraan bermotor.

\section{Bea Balik Nama Kendaraan Bermotor}

Menurut Undang-undang Nomor 28 tahun 2009 tentang Pajak Daerah dan Retribusi Daerah disebutkan bahwa,"Bea Balik Nama Kendaraan Bermotor adalah pajak atas penyerahan hak milik kendaraan bermotor sebagai akibat perjanjian dua pihak atau perbuatan sepihak atau keadaan yang terjadi karena jual beli, tukar menukar, hibah, warisan, atau pemasukan ke dalam badan usaha".

Menurut Marihot Pahala Siahaan (2010:209), "Bea Balik Nama Kendaraan Bermotor adalah pajak atas penyerahan hak milik kendaraan bermotor sebagai akibat perjanjian dua belah pihak atau perbuatan sepihak atau keadaan yang terjadi karena jual beli, tukar menukar, hibah, warisan, atau pemasukan ke dalam badan usaha".

Dengan demikian dapat ditarik kesimpulan bahwa Bea Balik Nama Kendaraan Bermotor adalah pajak atas penyerahan hak milik kendaraan bermotor sebagai akibat dari perjanjian anatara kedua belah pihak atau sepihak dikarenakan adanya jual beli, tukar menukar, warisan atau hibah.

\section{Pajak Bahan Bakar Kendaraan Bermotor}

Menurut Undang-undang Nomor 28 tahun 2009 tentang Pajak Daerah dan Retribusi Daerah yaitu, "Pajak Bahan Bakar Kendaraan Bermotor pajak atas penggunaan bahan bakar kendaraan bermotor. Bahan bakar kendaraan bermotor adalah semua jenis bahan bakar cair atau gas yang digunakan untuk kendaraan bermotor". Pengenaan Pajak Bahan Bakar Kendaraan Bermotor tidak mutlak ada pada seluruh daerah provinsi yang ada di Indonesia. Karena itu untuk dapat dipungut pada suatu daerah provinsi maka pemerintah daerah harus mengeluarkan atau menerbitkan Peraturan Daerah tentang Pajak Bahan Bakar Kendaraan Bermotor yang akan menjadi landasan hukum dalam teknis pelaksanaan pengenaan dan pemungutan Pajak Bahan Bakar Kendaraan Bermotor di daerah provinsi yang bersangkutan.

\section{Pendapatan Asli Daerah}

Berbicara tentang Pajak Daerah dan Retribusi Daerah sebagaimana disebutkan di atas tentunya tidak terlepas dari Pendapatan Asli Daerah. Berdasarkan ketentuan Pasal 1angka 18 Undang-Undang Nomor 33 Tahun 2004 tentang Perimbangan Keuangan Antara Pusat dan Daerah dijelaskan pengertian "Pendapatan Asli Daerah adalah pendapatan yang diperoleh daerah yang dipungut berdasarkan Peraturan Daerah sesuai dengan Peraturan PerundangUndangan". Dan menurut Aries Djaenuri (2012:88) menyatakan bahwa "Pendapatan asli Daerah adalah penerimaan yang diperoleh dari sumber-sumber dalam wilayah sendiri yang dipungut berdasarkan peraturan daerah sesuai dengan peraturan perundang-undangan yang berlaku".

Jadi, dapat ditarik kesimpulan bahwa pendapatan asli daerah merupakan pendapatan yang dapat dipungut oleh pemerintah daerah berasal dari sumber-sumber wilayah tiap daerah itu sendiri berdasarkan peraturan perundang-undangan yang berlaku.

\section{Pengembangan Hipotesis}

\section{Pengaruh Pajak Kendaraan Bermotor terhadap Pendapatan Asli Daerah}

Berdasarkan penelitian terdahulu yang dilakukan oleh Novita Ersady (2010), Marisa Natalina (2013), Riama Evi Aprianti (2013) dan Zulkifli (2013) yang menyebutkan bahwa terdapat pengaruh yang positif antara Pajak Kendaraan Bermotor terhadap Pendapatan Asli Daerah Provinsi Banten. Dari penelitian tersebut maka penulis menentukan hipotesis yang pertama mengenai pengaruh Pajak Kendaraan Bermotor terhadap Pendapatan Asli Daerah yaitu:

Ha1 Terdapat pengaruh positif dan signifikan Pajak Kendaraan Bermotor terhadap Pendapatan Asli Daerah Provinsi Jawa Barat Pada Cabang Dinas Pendapatan Daerah Provinsi Jawa Barat 


\section{Pengaruh Bea Balik Nama Kendaraan Bermotor Terhadap Pendapatan Asli Daerah}

Berdasarkan penelitian yang terdahulu yang dilakukan oleh Apri Mardiansah (2013:90) yang menyebutkan bahwa terdapat pengaruh yang positif antara Bea Balik Nama Kendaraan Bermotor terhadap Pendapatan Asli Daerah Provinsi Banten. Dari penelitian tersebut maka penulis menentukan hipotesis yang kedua mengenai pengaruh Bea Balik Nama Kendaraan Bermotor terhadap Pendapatan Asli Daerah yaitu:

$\mathrm{Ha}_{2}$ Terdapat pengaruh positif dan signifikan Bea Balik Nama Kendaraan Bermotor terhadap Pendapatan Asli Daerah Provinsi Jawa Barat Pada Cabang Dinas Pendapatan Daerah Provinsi Jawa Barat

Pengaruh Pajak Bahan Bakar Kendaraan Bermotor Terhadap Pendapatan Asli Daerah

Berdasarkan penelitian terdahulu yang telah dilakukan oleh Riama Evi Aprianti (2013) yang menyebutkan bahwa terdapat pengaruh yang positif tetapi tidak signifikan antara Pajak Bahan Bakar Kendaraan Bermotor terhadap Pendapatan Asli Daerah Provinsi Provinsi Jawa Barat. Dari penelitian tersebut berdasarkan kondisi saat ini dikarenakan harga bahan bakar kendaraan bermotor mengalami kenaikan dan juga semakin meningkatnya pertumbuhan jumlah kendaraan bermotor, maka penulis menentukan hipotesis yang ketiga mengenai pengaruh Pajak Bahan Bakar Kendaraan Bermotor terhadap Pendapatan Asli Daerah, yaitu:

Ha3 Terdapat pengaruh positif dan signifikan Pajak Bahan Bakar Kendaraan Bermotor terhadap Pendapatan Asli Daerah Provinsi Jawa Barat Pada Cabang Dinas Pendapatan Daerah Provinsi Jawa Barat

Pengaruh Pajak Kendaraan Bermotor terhadap Pendapatan Asli Daerah Dengan Pajak Bahan Bakar kendaraan Bermotor Sebagai variabel Moderasi

Berdasarkan penelitian terdahulu yang telah dilakukan oleh Riama Evi Aprianti (2013) yang menyebutkan bahwa Pajak Kendaraan Bermotor, Bea Balik Nama Kendaraan Bermotor dan Pajak Bahan Bakar Kendaraan Bermotor berpengaruh positif dan signifikan terhadap Pendapatan Asli Daerah. Namun, dalam penelitian ini terjadi pengembangan penelitian variabel dimana variabel Pajak Bahan Bakar Kendaraan Bermotor dijadikan sebagai variabel moderasi. Maka penulis menentukan hipotesis keempat yaitu:

$\mathrm{Ha}_{4}$ Terdapat pengaruh positif dan signifikan Pajak Kendaraan Bermotor terhadap Pendapatan Asli Daerah dengan Pajak Bahan Bakar Kendaraan Bermotor sebagai variabel moderating pada Cabang Dinas Pendapatan Daerah Provinsi Jawa Barat.

Pengaruh Bea Balik Nama Kendaraan Bermotor terhadap Pendapatan Asli Daerah Dengan Pajak Bahan Bakar kendaraan Bermotor Sebagai variabel Moderasi

Berdasarkan penelitian terdahulu yang telah dilakukan oleh Riama Evi Aprianti (2013) yang menyebutkan bahwa Pajak Kendaraan Bermotor, Bea Balik Nama Kendaraan Bermotor dan Pajak Bahan Bakar Kendaraan Bermotor berpengaruh positif dan signifikan terhadap Pendapatan Asli Daerah. Namun, dalam penelitian ini terjadi pengembangan penelitian variabel dimana variabel Pajak Bahan Bakar Kendaraan Bermotor dijadikan sebagai variabel moderasi. Maka penulis menentukan hipotesis kelima yaitu:

Ha5 Terdapat pengaruh positif dan signifikan Bea Balik Nama Kendaraan Bermotor terhadap Pendapatan Asli Daerah dengan Pajak Bahan Bakar Kendaraan Bermotor sebagai variabel moderating pada Cabang Dinas Pendapatan Daerah Provinsi Jawa Barat.

Pengaruh Pajak Kendaraan Bermotor dan Bea Balik Nama Kendaraan Bermotor Terhadap Pendapatan Asli Daerah

Berdasarkan penelitian terdahulu yang telah dilakukan oleh Riama Evi Aprianti (2013) dan Zulkifli (2013) secara simultan menemukan bahwa terdapat pengaruh positif dan signifikan antara Penerimaan Pajak Kendaraan Bermotor, Bea Balik Nama Kendaraan Bermotor dan Pajak Bahan Bakar Kendaraan Bermotor terhadap Pendapatan Asli Daerah, maka penulis menentukan hipotesis yang ketiga untuk mengetahui pengaruh secara bersama- 
sama antara pajak Kendaraan Bermotor, Bea Balik Nama Kendaraan Bermotor dan Pajak Bahan Bakar Kendaraan Bermotor terhadap Pendapatan Asli Daerah, maka hipotesisnya yaitu:

Ha6 Terdapat pengaruh positif dan signifikan Pajak Kendaraan Bermotor dan Bea Balik

Nama Kendaraan Bermotor terhadap Pendapatan Asli Daerah pada Cabang Dinas

Pendapatan Provinsi Jawa Barat

Pengaruh Pajak Kendaraan Bermotor dan Bea Balik Nama Kendaraan Bermotor Terhadap Pendapatan Asli Daerah Dengan Pajak Bahan Bakar kendaraan Bermotor Sebagai variabel Moderasi

Berdasarkan penelitian terdahulu yang telah dilakukan oleh Riama Evi Aprianti (2013) yang menyebutkan bahwa Pajak Kendaraan Bermotor, Bea Balik Nama Kendaraan Bermotor dan Pajak Bahan Bakar Kendaraan Bermotor berpengaruh positif dan signifikan terhadap Pendapatan Asli Daerah. Namun, dalam penelitian ini terjadi pengembangan penelitian dimana variabel Pajak Bahan Bakar Kendaraan Bermotor dijadikan sebagai variabel moderasi. Maka penulis menentukan hipotesis ketujuh yaitu:

Ha7 Terdapat pengaruh positif dan signifikan Pajak Kendaraan Bermotor dan Bea Balik Nama Kendaraan Bermotor terhadap Pendapatan Asli Daerah dengan Pajak Bahan

Bakar Kendaraan Bermotor sebagai variabel moderating pada Cabang Dinas Pendapatan Provinsi Jawa Barat

\section{METODE PENELITIAN}

Menurut Sugiyono (2012:61), "populasi adalah wilayah generalisasi yang terdiri atas objek/subjek yang mempunyai kualitas dan karakteristik tertentu yang ditetapkan oleh peneliti untuk dipelajari dan kemudian ditarik kesimpulannya. Populasi dalam penelitian ini adalah laporan Pendapatan Asli Daerah Provinsi Jawa Barat. Sampel dalam penelitian ini adalah laporan Pajak Kendaraan Bermotor, Bea Balik Nama Kendaraan Bermotor, dan Pajak Bahan Bakar Kendaraan Bermotor dari tahun 2010 - 2014. Teknik penentuan sampelnya yaitu dengan menggunakan teknik non-probability sampling. Adapun cara penarikan sampelnya adalah menggunakan purposive sampling yaitu teknik pengambilan sampel berdasarkan pertimbangan/kriteria-kriteria tertentu. Dalam hal ini yang menjadi kriteria pengambilan keputusan untuk dijadikan sampel adalah laporan terbaru. Jadi, sampel dalam penelitian ini adalah laporan penerimaan pajak Provinsi Jawa Barat terhitung dari tahun 2010-2014.

Data yang digunakan dalam penelitian ini adalah data sekunder. Teknik pengumpulan data lain yang digunakan adalah melalui observasi dan wawancara terstruktur dengan pimpinan dan karyawan instansi Dinas Pendapatan Provinsi Jawa Barat.

Teknik pengujian hipotesis dimulai dengan menghitung uji asumsi klasik yang merupakan persyaratan statistik yang harus dipenuhi pada analisis regresi linier berganda yang berbasis Ordinary Least Square (OLS) yang artinya analisis regresi memerlukan persyaratan asumsi klasik. Untuk regresi linier berganda terdapat empat uji asumsi klasik yang sering digunakan, yaitu uji normalitas, uji multikolinearitas, dan uji heteroskedastisitas. Setelah itu melakukan uji hipotesis yang terdiri dari korelasi product moment, uji t, koefisien determinasi, korelasi ganda, uji koefisien korelasi parsial, uji regresi berganda, uji F. Untuk Penelitian analisis ini menggunakan metode analisis regresi linear dengan metode absolut residual, yaitu model ini mirip dengan Multiple Regression Analysis (MRA), tetapi resiko variabel moderating didekati dengan selisih mutlak antara variabel bebas dengan variabel moderating lebih kecil gangguannya terhadap gangguan multikolinearitas dari pada dengan metode MRA. Semua uji yang telah diuraikan, dilakukan perhitungan dengan menggunakan program IBM SPSS Versi 22.0.

\section{Klasifikasi Variabel}

1. Variabel dependen adalah variabel yang besar kecilnya nilai ditentukan oleh besar 
kecilnya variabel independen. Dalam penelitian ini yang menjadi variabel dependen adalah pendapatan asli daerah (Y).

2. Variabel independen adal variabel yang menentukan besar kecilnya variabel dependen. Dalan penelitian ini yang menjadi variabel independen adalah pajak kendaraan bermotor (X1) dan bea balik nama kendaraan bermotor (X2).

3. Variabel pemoderasi adalah variabel yang memperkuat atau memperlemat hubungan antara variabel independen terhadap variabel dependen. Dalam penelitian ini yang menjadi variabel pemoderasi adalah pajak bahan bakar kendaraan bermotor $(Z)$.

\section{HASIL DAN PEMBAHASAN}

\section{HASIL PENELITIAN}

\section{Uji Asumsi Klasik}

Seperti yang telah dijelaskan pada bab sebelumnya, sebuah model regresi akan dapat dipakai untuk prediksi jika memenuhi sejumlah asumsi, yang disebut dengan asumsi klasik. Asumsi-asumsi yang biasanya dipakai yaitu sebagai berikut:

\section{Uji Normalitas}

Pengujian normalitas ini secara praktis dapat dilakukan melalui pembuatan grafik normal probability plot. Grafik dapat dilihat seperti gambar berikut ini:

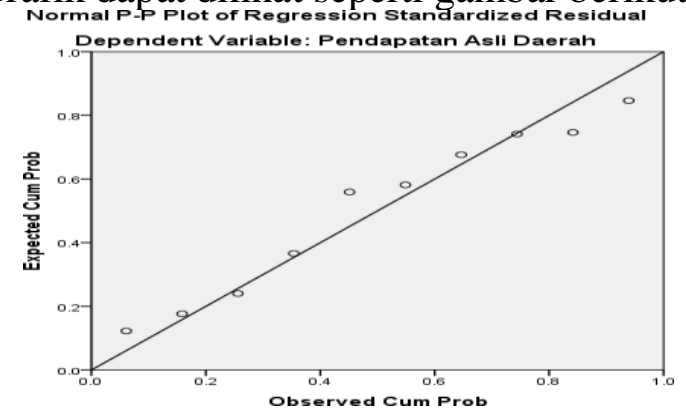

Gambar 1. Hasil Pengujian Normalitas dengan P-Plot Variabel Dependen Pendapatan Asli Daerah Sumber: diolah tahun 2015 dengan program SPSS versi 22

Berdasarkan Gambar 1 diatas, grafik pola menunjukan penyebaran titik-titik disekitar garis diagonal, dan mengikuti arah garis diagonal mengindikasikan model regresi memenuhi asumsi normal.

\section{Uji Multikolinearitas}

Pengujian ini dilakukan dengan mengukur besar korelasi antar variabel independen, jika dua variabel independen terbukti berkorelasi secara kuat, maka dikatakan terdapat multikolinearitas pada variabel tersebut.

Tabel 1. Hasil Pengujian Multikolinearitas

\begin{tabular}{lll}
\hline \multicolumn{4}{c}{ Coefficients $^{\mathrm{a}}$} & & \\
\hline Model & \multicolumn{2}{c}{ Collinearity Statistics } \\
\hline 1 (Constant) & & \\
\hline Zscore: Pajak Kendaraan Bermotor & .222 & 4.513 \\
\hline Zscore: Bea Balik Nama Kendaraan Bermotor & .207 & 4.831 \\
\hline $\begin{array}{l}\text { Zscore: Pajak Bahan Bakar Kendaraan } \\
\text { Bermotor }\end{array}$ & .534 & 1.874 \\
\hline Moderating & & \\
\hline a. Dependent Variable: Pendapatan Asli Daerah & & \\
\hline
\end{tabular}

Berdasarkan nilai VIF diketahui nilai VIF sebesar 4,513; 4,831; 1,874 dan 1,243 yang berarti kurang $<10$. Dengan demikian dapat disimpulkan tidak terjadi multikolineritas. 


\section{Uji Auto Korelasi}

Uji Auto korelasi bertujuan untuk menguji apakah dalam suatu model regresi linear ada atau tidaknya penyimpangan asumsi klasik auto korelasi korelasi yang terjadi antara residual pada satu pengamatan dengan pengamatan lain pada model regresi. Beberapa uji statistik yang sering digunakan adalah uji Durbin-Watson.

\section{Tabel 2. Hasil Uji Auto Korelasi}

\begin{tabular}{lccccc} 
& \multicolumn{4}{c}{ Model Summary $^{\mathbf{b}}$} \\
\hline & & $\mathrm{R}$ & Adjusted & Std. Error of the Durbin- \\
Model & $\mathrm{R}$ & Square & R Square & Estimate & Watson \\
\hline 1 & $.998^{\mathrm{a}} .995$ & .993 & 126064786117.1 & 2.448 \\
& & \multicolumn{4}{c}{04} \\
\hline
\end{tabular}

a. Predictors: (Constant), PBBKB, PKB, BBNKB

b. Dependent Variable: PAD

Sumber: diolah tahun 2015 dengan program SPSS versi 22

Dari hasil output dengan menggunakan program SPSS versi 22 diatas, nilai DurbinWatson adalah sebesar 2,448. Autokorelasi tidak terjadi jika angka Durbin-Watson $1<\mathrm{DW}<$ 3. Perhitungan berdasarkan data observasi menghasilkan tidak terjadi autokorelasi. Karena nilai DW sebesar 2,448 yang artinya nilai DW $1<2,448<3$.

Uji Heteroskedastisitas

Uji Heterokedastisitas untuk menguji apakah dalam model regresi terjadi adanya ketidakkesamaan varian dari residual satu pengamatan ke pengamatan lainnya.

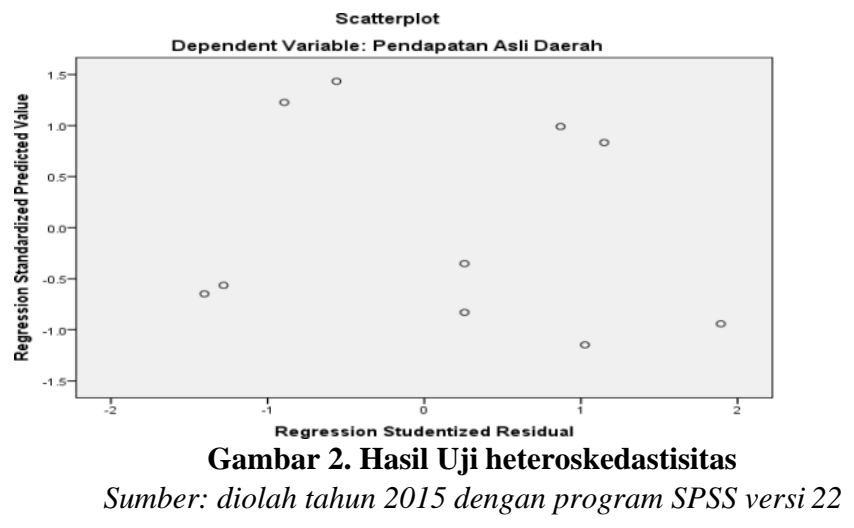

Dari hasil gambar 2 dengan melihat penyebaran titik-titik yang acak baik diatas maupun dibawah angka 0 , serta penyebaran titik-titik tidak membentuk pola bergelombang melebar kemudian menyempit dan melebar kembali. Dapat disimpulkan tidak terjadi heteroskedastisitas.

\section{Pengaruh Pajak Kendaraan Bermotor Terhadap Pendapatan Asli Daerah Provinsi Jawa Barat}

Untuk melihat seberapa besar korelasi sederhana antara Pajak Kendaraan Bermotor terhadap Pendapatan Asli Daerah dapat dilihat pada tabel berikut ini:

Tabel 3. Hasil Korelasi antara Pajak Kendaraan Bermotor terhadap Pendapatan Asli Daerah Provinsi Jawa Barat

\begin{tabular}{cc}
\hline Variabel & Pendapatan Asli Daerah \\
\hline Pumber: diolah tahun 2015 dengan program SPSS versi 2
\end{tabular}

Hipotesis yang akan diuji adalah korelasi antara Pajak Kendaraan Bermotor terhadap Pendapatan Asli Daerah Provinsi jawa Barat. Dari perhitungan bivariat diperoleh nilai $\mathrm{r}=$ 0,922, seperti yang tertera di interprestasi nilai korelasi, jika $r>0$ dan apabila interval 
koefisien korelasi berada pada nilai 0,80 - 1,000 artinya ada hubungan yang sangat kuat antara variabel Pajak Kendaraan Bermotor dengan variabel Pendapatan Asli Daerah. Apabila terdapat korelasi antara Pajak Kendaraan Bermotor terhadap Pendapatan Asli Daerah, hal ini menunjukkan bahwa dengan meningkatnya Pajak Kendaraan Bermotor maka penerimaan Pendapatan Asli Daerah juga meningkat.

Berdasarkan hasil perhitungan pada Pajak Kendaraan Bermotor diperoleh nilai thitung $>$ tabel yang berarti Pajak Kendaraan Bermotor berpengaruh secara parsial terhadap Pendapatan Asli Daerah, dengan taraf signifikan $\alpha=0,05$ (5\%), maka dengan nilai signifikan sebesar $0,000<0,05$ yang berarti Pajak Kendaraan Bermotor signifikan terhadap Pendapatan Asli Daerah. Hal ini menunjukan bahwa Ha1 diterima, yang berarti Pajak Kendaraan Bermotor berpengaruh positif dan signifikan terhadap Pendapatan Asli Daerah.

Pengaruh Bea Balik Nama Kendaraan Bermotor Terhadap Pendapatan Asli Daerah Provinsi Jawa Barat

Untuk melihat seberapa besar korelasi sederhana antara Bea Balik Nama Kendaraan Bermotor terhadap Pendapatan Asli Daerah dapat dilihat pada tabel berikut ini:

Tabel 4. Hasil Korelasi antara Bea Balik Nama Kendaraan Bermotor terhadap Pendapatan Asli Daerah Provinsi Jawa Barat

\begin{tabular}{cc}
\hline Variabel & Pendapatan Asli Daerah \\
\hline Bea Balik Nama Kendaraan Bermotor & $0,989^{* *}$ \\
\hline Sumber: diolah tahun 2015 dengan program SPSS versi 22
\end{tabular}

Hipotesis yang akan diuji adalah korelasi antara Bea Balik Nama Kendaraan Bermotor terhadap Pendapatan Asli Daerah Provinsi jawa Barat. Dari perhitungan bivariat diperoleh nilai $\mathrm{r}=0,989$, seperti yang tertera di interprestasi nilai korelasi, jika $\mathrm{r}>0$ dan apabila interval koefisien korelasi berada pada nilai 0,80 - 1,000 artinya ada hubungan yang sangat kuat antara variabel Bea Balik Nama Kendaraan Bermotor dengan variabel Pendapatan Asli Daerah. Apabila terdapat korelasi antara Bea Balik Nama Kendaraan Bermotor terhadap Pendapatan Asli Daerah, hal ini menunjukkan bahwa dengan meningkatnya Bea Balik Nama Kendaraan Bermotor maka penerimaan Pendapatan Asli Daerah juga meningkat.

Berdasarkan hasil perhitungan pada Bea Balik Nama Kendaraan Bermotor diperoleh nilai thitung $>t_{\text {tabel }}$ yang berarti Bea Balik Nama Kendaraan Bermotor berpengaruh secara parsial terhadap Pendapatan Asli Daerah, dengan taraf signifikan $\alpha=0,05(5 \%)$, dengan nilai signifikan sebesar 0,000 < 0,05 yang berarti Bea Balik Nama Kendaraan Bermotor signifikan terhadap Pendapatan Asli Daerah. Hal ini menunjukan bahwa Ha2 diterima, yang berarti Bea Balik Nama Kendaraan Bermotor berpengaruh positif dan signifikan terhadap Pendapatan Asli Daerah.

\section{Pengaruh Pajak Bahan Bakar Kendaraan Bermotor Terhadap Pendapatan Asli Daerah Provinsi Jawa Barat}

Untuk melihat seberapa besar korelasi sederhana antara Pajak Bahan Bakar Kendaraan Bermotor terhadap Pendapatan Asli Daerah dapat dilihat pada tabel berikut ini:

Tabel 5. Hasil Korelasi antara Pajak Bahan Bakar Kendaraan Bermotor terhadap Pendapatan Asli Daerah Provinsi Jawa Barat

\begin{tabular}{cc}
\hline Variabel & Pendapatan Asli Daerah \\
\hline Pajak Bahan Bakar Kendaraan Bermotor & $0,706^{*}$ \\
\hline Sumber: diolah tahun 2015 dengan program SPSS versi 22
\end{tabular}

Hipotesis yang akan diuji adalah korelasi antara Pajak Bahan Bakar Kendaraan Bermotor terhadap Pendapatan Asli Daerah Provinsi jawa Barat. Dari perhitungan bivariat diperoleh nilai $\mathrm{r}=0,706$, seperti yang tertera di interprestasi nilai korelasi, jika $\mathrm{r}>0$ dan apabila interval koefisien korelasi berada pada nilai 0,60 - 0,799 artinya ada hubungan yang kuat antara variabel Pajak Bahan Bakar Kendaraan Bermotor dengan variabel Pendapatan Asli 
Daerah.

Apabila terdapat korelasi antara Pajak Bahan Bakar Kendaraan Bermotor terhadap Pendapatan Asli Daerah, hal ini menunjukkan bahwa dengan meningkatnya Pajak Bahan Bakar Kendaraan Bermotor maka penerimaan Pendapatan Asli Daerah juga meningkat.

Berdasarkan hasil perhitungan pada Pajak Bahan Bakar Kendaraan Bermotor diperoleh nilai thitung $>t_{\text {tabel }}$ yang berarti Pajak Bahan Bakar Kendaraan Bermotor berpengaruh secara parsial terhadap Pendapatan Asli Daerah taraf signifikan $\alpha=0,05$ (5\%), dengan nilai signifikan sebesar 0,023 $<0,05$ yang berarti Pajak Bahan Bakar Kendaraan Bermotor signifikan terhadap Pendapatan Asli Daerah. Hal ini menunjukan bahwa $\mathrm{Ha}_{3}$ diterima, yang berarti Pajak Bahan Bakar Kendaraan Bermotor berpengaruh positif dan signifikan terhadap Pendapatan Asli Daerah.

Pengaruh Pajak Kendaraan Bermotor dan Bea Balik Nama Kendaraan Bermotor terhadap Pendapatan Asli Daerah Provinsi Jawa Barat

Untuk melihat seberapa besar koefisien korelasi berganda antara Pajak Kendaraan Bermotor dan Bea Balik Nama Kendaraan Bermotor terhadap Pendapatan Asli Daerah dapat dilihat pada tabel berikut ini:

Tabel 6. Hasil Koefisien Korelasi Berganda antara Pajak Kendaraan Bermotor dan Bea Balik Nama Kendaraan Bermotor terhadap Pendapatan Asli Daerah Provinsi Jawa Barat

\begin{tabular}{ccc}
\hline Variabel & R & R Square \\
\hline $\begin{array}{c}\text { Pajak Kendaraan Bermotor, Bea Balik Nama } \\
\text { Kendaraan Bermotor }\end{array}$ & 0.995 & 0.990 \\
\hline
\end{tabular}

sumber: diolah tahun 2015 dengan program SPSS versi 22

Hipotesis yang akan diuji adalah korelasi antara Pajak Kendaraan Bermotor dan Bea Balik Nama Kendaraan Bermotor terhadap Pendapatan Asli Daerah Provinsi jawa Barat. Dari perhitungan bivariat diperoleh nilai $r=0,990$ artinya ada hubungan yang sangat kuat antara variabel Pajak Kendaraan Bermotor dan Bea Balik Nama Kendaraan Bermotor dengan variabel Pendapatan Asli Daerah.

Apabila terdapat korelasi antara Pajak Kendaraan Bermotor dan Bea Balik Nama Kendaraan Bermotor terhadap Pendapatan Asli Daerah, hal ini menunjukkan bahwa dengan meningkatnya Bea Balik Nama Kendaraan Bermotor maka penerimaan Pendapatan Asli Daerah juga meningkat.

Berdasarkan hasil perhitungan diperoleh nilai $F_{h i t u n g} 348,697>F_{\text {tabel }}$ 4,74 yang berarti Pajak Kendaraan Bermotor dan Bea Balik Nama kendaraan Bermotor berpengaruh secara simultan terhadap Pendapatan Asli Daerah, dan dengan nilai signifikan sebesar 0,000 $<0,05$ Hal ini menunjukan bahwa Ha4 diterima, yang berarti Pajak Kendaraan Bermotor dan Bea Balik Nama Kendaraan Bermotor berpengaruh positif dan signifikan terhadap Pendapatan Asli Daerah.

\section{Pengaruh Pajak Kendaraan Bermotor terhadap Pendapatan Asli Daerah Provinsi Jawa} Barat dengan Pajak Bahan Bakar Kendaraan Bermotor sebagai Variabel Moderating

Untuk melihat seberapa besar Koefisien Determinasi antara Pajak Kendaraan Bermotor terhadap Pendapatan Asli Daerah dengan Pajak Bahan Bakar Kendaraan Bermotor sebagai variabel moderating dapat dilihat pada tabel berikut ini: 
Tabel 7. Hasil Koefisien Determinasi antara Pajak Kendaraan Bermotor terhadap Pendapatan Asli Daerah Provinsi Jawa Barat dengan Pajak Bahan Bakar Kendaraan Bermotor sebagai variabel moderating

\begin{tabular}{ccc}
\hline Variabel & R & R Square \\
\hline $\begin{array}{c}\text { Pajak Kendaraan Bermotor dan Pajak Bahan } \\
\text { Bakar Kendaraan Bermotor }\end{array}$ & 0.938 & 0.879 \\
$\begin{array}{l}\text { Sumber: diolah tahun 2015 dengan program SPSS versi } 22 \\
\end{array}$
\end{tabular}

Jadi nilai R Square pertama sebelum adanya variabel moderating sebesar 0,850 atau $85 \%$ sedangkan setelah adanya persamaan yang kedua pada dengan variabel moderating naik menjadi 0,879 atau 87,9\%. Jadi kesimpulannya, dengan adanya Pajak Bahan Bakar Kendaraan Bermotor memperkuat hubungan antara Pajak Kendaraan Bermotor terhadap Pendapatan Asli Daerah.

Berdasarkan hasil perhitungan diperoleh nilai $F_{h i t u n g} 14,575>F_{\text {tabel }} 4,757$ yang berarti Pajak Kendaraan Bermotor dan Pajak Bahan Bakar Kendaraan Bermotor sebagai Variabel Moderating berpengaruh secara simultan terhadap Pendapatan Asli Daerah, dan dengan nilai signifikan sebesar 0,004 < 0,05. Hal ini menunjukan bahwa Has diterima, yang berarti Pajak Kendaraan Bermotor dan Pajak Bahan Bakar Kendaraan Bermotor sebagai variabel moderating berpengaruh positif dan signifikan terhadap Pendapatan Asli Daerah.

Pengaruh Bea Balik Nama Kendaraan Bermotor terhadap Pendapatan Asli Daerah Provinsi Jawa Barat dengan Pajak Bahan Bakar Kendaraan Bermotor sebagai Variabel Moderating

Untuk melihat seberapa besar Koefisien Determinasi antara Bea Balik Nama Kendaraan Bermotor terhadap Pendapatan Asli Daerah dengan Pajak Bahan Bakar Kendaraan Bermotor sebagai variabel moderating dapat dilihat pada tabel berikut ini:

Tabel 8. Hasil Koefisien Determinasi antara Bea Balik Nama Kendaraan Bermotor terhadap Pendapatan Asli Daerah Provinsi Jawa Barat dengan Pajak Bahan Bakar Kendaraan Bermotor sebagai variabel moderating

\begin{tabular}{lcc}
\hline \multicolumn{1}{c}{ Variabel } & R & R Square \\
\hline $\begin{array}{l}\text { Bea Balik Nama Kendaraan Bermotor dan } \\
\text { Pajak Bahan Bakar Kendaraan Bermotor }\end{array}$ & 0.993 & 0.987 \\
\hline sumber:diolah tahun 2015 dengan programm SPSS versi 22 &
\end{tabular}

Jadi nilai R Square pertama sebelum adanya variabel moderating sebesar 0,978 atau 97,8\% sedangkan setelah adanya persamaan yang kedua pada dengan variabel moderating naik menjadi 0,987 atau 98,7\%. Jadi kesimpulannya, dengan adanya Pajak Bahan Bakar Kendaraan Bermotor memperkuat hubungan antara Bea Balik Nama Kendaraan Bermotor terhadap Pendapatan Asli Daerah.

Berdasarkan hasil perhitungan diperoleh nilai $F_{\text {hitung }} 155,282>\mathrm{F}_{\text {tabel }} 4,757$ yang berarti Bea Balik Nama kendaraan Bermotor dan Pajak Bahan Bakar Kendaraan Bermotor sebagai Variabel Moderating berpengaruh secara simultan terhadap Pendapatan Asli Daerah, dan dengan nilai signifikan sebesar 0,000 < 0,05 Hal ini menunjukan bahwa $\mathrm{Ha}_{6}$ diterima, yang berarti Bea Balik Nama Kendaraan Bermotor dan Pajak Bahan Bakar Kendaraan Bermotor sebagai variabel moderating berpengaruh positif dan signifikan terhadap Pendapatan Asli Daerah.

Pengaruh Pajak Kendaraan Bermotor dan Bea Balik Nama Kendaraan Bermotor terhadap Pendapatan Asli Daerah Provinsi Jawa Barat dengan Pajak Bahan Bakar Kendaraan Bermotor sebagai variabel moderating

Untuk melihat seberapa besar koefisien korelasi berganda antara Pajak Kendaraan 
Bermotor dan Bea Balik Nama Kendaraan Bermotor terhadap Pendapatan Asli Daerah dengan Pajak Bahan Bakar Kendaraan Bermotor sebagai variabel moderating dapat dilihat pada tabel berikut ini:

Tabel 9. Hasil Koefisien Korelasi Berganda antara Pajak Kendaraan Bermotor dan Bea Balik Nama Kendaraan Bermotor terhadap Pendapatan Asli Daerah Provinsi Jawa Barat dengan Pajak Bahan Bakar Kendaraan Bermotor sebagai Variabel Moderating

\begin{tabular}{ccc}
\hline Variabel & R & R Square \\
\hline $\begin{array}{c}\text { Pajak Kendaraan Bermotor, Bea Balik } \\
\text { Nama Kendaraan Bermotor, dan Pajak } \\
\text { Bahan Bakar Kendaraaan Bermotor }\end{array}$ & 0.998 & 0.995 \\
\hline
\end{tabular}

Sumber: diolah tahun 2015 dengan program SPSS versi 22

Jadi nilai R Square pertama sebelum adanya variabel moderating sebesar 0,990 atau 99\% sedangkan setelah adanya persamaan yang kedua pada dengan variabel moderating naik menjadi 0,995 atau 99,5\%. Jadi kesimpulannya, dengan adanya Pajak Bahan Bakar Kendaraan Bermotor memperkuat hubungan antara Pajak Kendaraan Bermotor dan Bea Balik Nama Kendaraan Bermotor terhadap Pendapatan Asli Daerah.

Berdasarkan hasil perhitungan diperoleh nilai $F_{\text {hitung }} 268,984>\mathrm{F}_{\text {tabel }} 4,757$ yang berarti Pajak Kendaraan Bermotor, Bea Balik Nama Kendaraan Bermotor dan Pajak Bahan Bakar Kendaraan Bermotor sebagai variabel moderating berpengaruh secara simultan terhadap Pendapatan Asli Daerah, dan dengan nilai signifikan sebesar 0,000 $<0,05$. Hal ini menunjukan bahwa Ha7 diterima, yang berarti Pajak Kendaraan Bermotor, Bea Balik Nama Kendaraan Bermotor dan Pajak Bahan Bakar Kendaraan Bermotor sebagai variabel moderating berpengaruh positif dan signifikan terhadap Pendapatan Asli Daerah.

\section{PEMBAHASAN}

\section{Pengaruh Pajak Kendaraan Bermotor Terhadap Pendapatan Asli Daerah Provinsi Jawa Barat}

Berdasarkan hasil perhitungan pada Tabel 3 tentang Pajak Kendaraan Bermotor diperoleh nilai thitung $>$ tabel yang berarti Pajak Kendaraan Bermotor berpengaruh secara parsial terhadap Pendapatan Asli Daerah, dengan taraf signifikan $\alpha=0,05(5 \%)$, maka dengan nilai signifikan sebesar $0,000<0,05$ yang berarti Pajak Kendaraan Bermotor signifikan terhadap Pendapatan Asli Daerah. Hal ini menunjukan bahwa $\mathrm{Ha}_{1}$ diterima, yang berarti Pajak Kendaraan Bermotor berpengaruh positif dan signifikan terhadap Pendapatan Asli Daerah. Hasil ini sama seperti penelitian terdahulu yang dilakukan oleh Marisa (2013). Pemerintah Provinsi Jawa Barat melakukan pembenahan sistem dalam hal melayani masyarakat yang akan membayarkan Pajak Kendaraan Bermotor. Dengan adanya terobosan baru diberlakukannya system Drive Thrue, yaitu masyarakat yang akan membayar pajak kendaraan bermotor tidak perlu lagi turun dari kendaraannya, cukup mengantri seperti halnya mengantri di loket gerbang tol. Sehingga masyarakat merasa terbantu dengan adanya system tersebut, masyarakat merasa waktu yang diperlukan dalam melakukan pembayaran tidak menyita waktu.

\section{Pengaruh Bea Balik Nama Kendaraan Bermotor Terhadap Pendapatan Asli Daerah Provinsi Jawa Barat}

Berdasarkan hasil perhitungan pada Tabel 4 tentang Bea Balik Nama Kendaraan Bermotor diperoleh nilai thitung $>t_{\text {tabel }}$ yang berarti Bea Balik Nama Kendaraan Bermotor berpengaruh secara parsial terhadap Pendapatan Asli Daerah, dengan taraf signifikan $\alpha=0,05$ (5\%), dengan nilai signifikan sebesar 0,000 < 0,05 yang berarti Bea Balik Nama Kendaraan Bermotor signifikan terhadap Pendapatan Asli Daerah. Hal ini menunjukan bahwa Ha2 
diterima, yang berarti Bea Balik Nama Kendaraan Bermotor berpengaruh positif dan signifikan terhadap Pendapatan Asli Daerah. Hasil ini sama seperti penelitian terdahulu yang dilakukan oleh Mardiansah (2013). Hal ini dikarenakan banyaknya penjualan kendaraan bermotor khususnya roda 4(empat) yang jika kendaraannya akan dibuat BBNKB dari pihak pertama dealer diubah ke pihak kedua yaitu pembeli, dan juga disebabkan banyaknya lembaga keuangan Bank dan Pegadaian yang memberikan layanan pinjaman dana dengan jaminan BPKB. Hal ini mendororng pemilik kendaraan bermotor mengurus BPKB yang dibeli dari tahun sebelumnya.

Pengaruh Pajak Bahan Bakar Kendaraan Bermotor Terhadap Pendapatan Asli Daerah Provinsi Jawa Barat

Berdasarkan hasil perhitungan pada tabel 5 Pajak Bahan Bakar Kendaraan Bermotor diperoleh nilai thitung $>$ tabel yang berarti Pajak Bahan Bakar Kendaraan Bermotor berpengaruh secara parsial terhadap Pendapatan Asli Daerah taraf signifikan $\alpha=0,05$ (5\%), dengan nilai signifikan sebesar 0,023 $<0,05$ yang berarti Pajak Bahan Bakar Kendaraan Bermotor signifikan terhadap Pendapatan Asli Daerah. Hal ini menunjukan bahwa Haz diterima, yang berarti Pajak Bahan Bakar Kendaraan Bermotor berpengaruh positif dan signifikan terhadap Pendapatan Asli Daerah. Hasil ini berbeda dengan penelitian terdahulu yang dilakukan oleh Riama Evi Aprianti dimana hasil penelitian yang dilakukan positif tetapi tidak signifikan. Hal ini dikarenakan tingginya konsumsi bahan bakar kendaraan bermotor yang disebabkan oleh tingginya pertumbuhan penggunaan kendaraan bermotor.

Pengaruh Pajak Kendaraan Bermotor dan Bea Balik Nama Kendaraan Bermotor terhadap Pendapatan Asli Daerah Provinsi Jawa Barat

Berdasarkan hasil perhitungan diperoleh nilai $F_{\text {hitung }} 348,697>\mathrm{F}_{\text {tabel }}$ 4,74 yang berarti Pajak Kendaraan Bermotor dan Bea Balik Nama kendaraan Bermotor berpengaruh secara simultan terhadap Pendapatan Asli Daerah, dan dengan nilai signifikan sebesar 0,000<0,05 Hal ini menunjukan bahwa Ha4 diterima, yang berarti Pajak Kendaraan Bermotor dan Bea Balik Nama Kendaraan Bermotor berpengaruh positif dan signifikan terhadap Pendapatan Asli Daerah. Hasil ini sama dengan penelitian terdahulu yang dilakukan oleh Riama (2013). Hal ini disebabkan kesadaran dari masyarakat serta sosialisasi dinas terkait tentang pentingnya Pajak Kendaraan Bermotor dan Bea Balik Nama Kendaraaan Bermotor terhadap Penerimaan Pajak Daerah.

Pengaruh Pajak Kendaraan Bermotor terhadap Pendapatan Asli Daerah Provinsi Jawa Barat dengan Pajak Bahan Bakar Kendaraan Bermotor sebagai Variabel Moderating

Nilai R Square pertama sebelum adanya variabel moderating sebesar 0,850 atau $85 \%$ sedangkan setelah adanya persamaan yang kedua pada dengan variabel moderating naik menjadi 0,879 atau $87,9 \%$. Jadi kesimpulannya, dengan adanya Pajak Bahan Bakar Kendaraan Bermotor memperkuat hubungan antara Pajak Kendaraan Bermotor terhadap Pendapatan Asli Daerah. Hal ini disebabkan semakin banyaknya kendaraan bermotor sehingga semakin banyak pula penggunaan bahan bakar.

Pengaruh Bea Balik Nama Kendaraan Bermotor terhadap Pendapatan Asli Daerah Provinsi Jawa Barat dengan Pajak Bahan Bakar Kendaraan Bermotor sebagai Variabel Moderating

Nilai R Square pertama sebelum adanya variabel moderating sebesar 0,978 atau 97,8\% sedangkan setelah adanya persamaan yang kedua pada dengan variabel moderating naik menjadi 0,987 atau 98,7\%. Jadi kesimpulannya, dengan adanya Pajak Bahan Bakar Kendaraan Bermotor memperkuat hubungan antara Bea Balik Nama Kendaraan Bermotor terhadap Pendapatan Asli Daerah.

Pengaruh Pajak Kendaraan Bermotor dan Bea Balik Nama Kendaraan Bermotor terhadap Pendapatan Asli Daerah Provinsi Jawa Barat dengan Pajak Bahan Bakar Kendaraan Bermotor sebagai variabel moderating 
nilai R Square pertama sebelum adanya variabel moderating sebesar 0,990 atau 99\% sedangkan setelah adanya persamaan yang kedua pada dengan variabel moderating naik menjadi 0,995 atau 99,5\%. Jadi kesimpulannya, dengan adanya Pajak Bahan Bakar Kendaraan Bermotor memperkuat hubungan antara Pajak Kendaraan Bermotor dan Bea Balik Nama Kendaraan Bermotor terhadap Pendapatan Asli Daerah.

\section{KESIMPULAN DAN SARAN}

Berdasarkan hasil penelitian dan pembahasan, maka dapat diambil kesimpulan bahwa:

1. Pajak Kendaraan Bermotor berpengaruh positif dan signifikan terhadap Pendapatan Asli Daerah.

2. Bea Balik Nama Kendaraan Bermotor berpengaruh positif dan signifikan terhadap Pendapatan Asli Daerah.

3. Pajak Bahan Bakar Kendaraan Bermotor berpengaruh positif dan signifikan terhadap Pendapatan Asli Daerah.

4. Pajak Kendaraan Bermotor dan Bea Balik Nama Kendaraan Bermotor berpengaruh positif dan signifikan terhadap Pendapatan Asli Daerah.

5. Pajak Kendaraan Bermotor dan Pajak Bahan Bakar Kendaraan Bermotor sebagai variabel moderating berpengaruh positif dan signifikan terhadap Pendapatan Asli Daerah.

6. Bea Balik Nama Kendaraan Bermotor dan Pajak Bahan Bakar Kendaraan Bermotor sebagai variabel moderating berpengaruh positif dan signifikan terhadap Pendapatan Asli Daerah.

7. Pajak Kendaraan Bermotor, Bea Balik Nama Kendaraan Bermotor dan Pajak Bahan Bakar Kendaraan Bermotor sebagai variabel moderating berpengaruh positif dan signifikan terhadap Pendapatan Asli Daerah.

Berdasarkan kesimpulan di atas, maka penulis memberikan saran-saran untuk memaksimalkan penerimaan Pendapatan Asli Daerah, adalah sebagai berikut:

1. Pajak Kendaraan Bermotor berpengaruh terhadap Pendapatan Asli Daerah, oleh karena itu masih diperlukannya sosialisasi terhadap masyarakat tentang pengetahuan tertib Pajak Kendaraan Bermotor dan perlu adanya fasilitator yang membantu masyarakat dalam menangani pertanyaan-pertanyaan perihal tentang Pajak Kendaraan Bermotor agar masyarakat lebih sadar tentang kewajiban membayar pajak, dan perlu diadakan pendataan ulang terhadap kepemilikan kendaraan bermotor agar dapat terlihat berapa banyak pemilik kendaraan bermotor yang belum membayarkan pajak kendaraan bermotornya sehingga penerimaan Pendapatan Asli Daerah bisa lebih dimaksimalkan guna kepentingan orang banyak.

2. Dinas Pendapatan lebih memaksimalkan lagi pemungutan-pemungutan pajak tersebut dengan cara melakukan pendataan ulang yang lebih lengkap terhadap objek maupun subjek pajak sehingga penerimaan Pendapatan Asli Daerah dapat diserap secara maksimal.

3. Meningkatkan kesadaran wajib pajak sebagai objek dan subjek pajak, sebagai penyerahan kendaraan bermotor dan pengguna bahan bakar kendaraan bermotor sesuai dengan peraturan yang sudah ditetapkan agar kedua belah pihak saling diuntungkan.

4. Meningkatkan monitoring terhadap subjek pajak Pajak Bahan Bakar Kendaraan Bermotor agar pembayaran Pajak Bahan Bakar Kendaraan Bermotor dan pelaporan Surat Pemberitahuan Pajak Daerah (SPTPD) oleh penyedia bahan bakar kendaraan bermotor setiap bulan sesuai dengan pemakaian.

\section{DAFTAR PUSTAKA}

Andi. (2013). Perpajakan: Esensi dan Aplikasi. ANDI. Yogyakarta. 
Aziz Samudra, Azhari. (2015). Perpajakan di Indonesia: Keuangan, Pajak dan Retribusi Daerah. Rajagrafindo Persada. Jakarta.

Djaenuri, Aries. (2012). Hubungan Keuangan Pusat-Daerah. Gramedia. Jakarta.

Evi Aprianti, Riama. (2013). Pengaruh Pajak Kendaraan Bermotor, Bea Balik Nama Kendaraan Bermotor dan Pajak Bahan Bakar Kendaraan Bermotor Terhadap Pendapatan Asli Daerah Provinsi Jawa Barat. Fakultas Ekonomi Universitas Kristen Maranatha. Bandung.

Fayrusz C.E, Muhammad. (2014). Jurnal Pengaruh Pajak Kendaraan Bermotor, Bea Balik Nama Kendaraan Bermotor, dan Pajak Air Permukaan Terhadap Pendapatan Asli Daerah Provinsi Kepulauan Riau. Fakultas Ekonomi Universitas Maritim Raja Ali Haji. Tanjung Pinang.

Mardiansah, Apri. (2013). Pengaruh Bea Balik Nama Kendaraan Bermotor Terhadap Pendapatan Asli Daerah Provinsi Banten. Fakultas Ekonomi Universitas Pamulang. Pamulang.

Mardiasmo. (2011). Perpajakan. Edisi Revisi. Andi. Yogyakarta.

Natalina, Marisa. (2013). Pengaruh Kontribusi Pajak Kendaraan Bermotor Terhadap Pendapatan Asli Daerah Provinsi Banten. Fakultas Ekonomi Universitas Pamulang. Pamulang.

Pahala Siahaan, Marihot. (2010). Pajak Daerah dan Retribusi Daerah. Raja Grafindo Persada. Jakarta.

Peraturan Daerah, Nomor 13 Tahun 2011 Tentang Pajak Daerah Provinsi Jawa Barat.

Peraturan Gubernur Jawa Barat, Nomor 75 Tahun 2010 Tentang Perhitungan Dasar Pengenaan Pajak Kendaraan Bermotor dan Bea Balik Nama Kendaraan Bermotor Tahun 2010.

Peraturan Gubernur Provinsi Jawa Barat, Nomor 28 Tahun 2012 Tentang Petunjuk Pelaksanaan Pajak Bahan Bakar Kendaraan Bermotor.

Peraturan Gubernur Jawa Barat, Nomor 33 Tahun 2013 Tentang Petunjuk Pelaksanaan Peraturan Daerah Provinsi Jawa Barat.

Pohan, Chairil Anwar. (2014). Perpajakan Indonesia: Teori dan Kasus. Mitra Wacana Media. Jakarta.

Purwono, Herry. (2010). Dasar-Dasar Perpajakan \& Akuntansi Pajak. Erlangga. Jakarta.

Republik Indonesia, Undang-Undang Nomor 33 Tahun 2004 Tentang Perimbangan Keuangan Antara Pemerintah Pusat dan Pemerintah Daerah.

Republik Indonesia, Undang-Undang Nomor 28 Tahun 2009 tentang Pajak Daerah dan Retribusi Daerah.

Resmi, Siti. (2009). Perpajakan : Teori dan Kasus. Salemba Empat. Jakarta.

Saidi, M. Djafar. (2007). Pembaruan Hukum Pajak. PT Raja Garfindo Persada. Jakarta.

Sari, Diana. (2013). Konsep Dasar Perpajakan. PT Refika Aditama. Bandung.

Siregar, Syofian. (2013). Metode Penelitian Kuantitatif. Kencana Prenadamedia. Jakarta.

Sujarweni, V. Wiratna. (2015). SPSS Untuk Penelitian. Pustaka Baru Press. Yogyakarta.

Sugianto. (2008). Pajak dan Retribusi Daerah. Grasindo. Jakarta.

Sugiyono. (2011). Metode Penelitian Kuantitatif Kualitatif dan R\&D. Alfabeta. Bandung. . (2012). Statistika Untuk Penelitian. Alfabeta. Bandung.

Universitas Pamulang. (2014). Pedoman Penulisan Skripsi. Universitas Pamulang. Pamulang. Waluyo. (2013). Perpajakan Indonesia. Edisi 11 Buku 1. Salemba Empat. Jakarta.

Zulkifli. (2013). Pengaruh Kontribusi Pajak Kendaraan Bermotor Dan Bea Balik Nama Kendaraan Bermotor Terhadap Peningkatan Pendapatan Asli Daerah Provinsi Gorontalo. Fakultas Ekonomi Dan Bisinis. Universitas Negeri Gorontalo. Sulawesi Utara. 